\title{
Aliphatic, Cyclic, and Aromatic Organic Acids, Vitamins, and Carbohydrates in Soil: A Review
}

\author{
Valerie Vranova, Klement Rejsek, and Pavel Formanek \\ Department of Geology and Soil Science, Mendel University in Brno, Zemedelska 3, 61300 Brno, Czech Republic \\ Correspondence should be addressed to Pavel Formanek; formanek@mendelu.cz
}

Received 1 August 2013; Accepted 15 September 2013

Academic Editors: M. Dunn and G. Liu

Copyright ( 2013 Valerie Vranova et al. This is an open access article distributed under the Creative Commons Attribution License, which permits unrestricted use, distribution, and reproduction in any medium, provided the original work is properly cited.

\begin{abstract}
Organic acids, vitamins, and carbohydrates represent important organic compounds in soil. Aliphatic, cyclic, and aromatic organic acids play important roles in rhizosphere ecology, pedogenesis, food-web interactions, and decontamination of sites polluted by heavy metals and organic pollutants. Carbohydrates in soils can be used to estimate changes of soil organic matter due to management practices, whereas vitamins may play an important role in soil biological and biochemical processes. The aim of this work is to review current knowledge on aliphatic, cyclic, and aromatic organic acids, vitamins, and carbohydrates in soil and to identify directions for future research. Assessments of organic acids (aliphatic, cyclic, and aromatic) and carbohydrates, including their behaviour, have been reported in many works. However, knowledge on the occurrence and behaviour of D-enantiomers of organic acids, which may be abundant in soil, is currently lacking. Also, identification of the impact and mechanisms of environmental factors, such as soil water content, on carbohydrate status within soil organic matter remains to be determined. Finally, the occurrence of vitamins in soil and their role in biological and biochemical soil processes represent an important direction for future research.
\end{abstract}

\section{Introduction}

Organic acids, vitamins, and carbohydrates play an important role in soil. Organic acids (aliphatic, cyclic, and aromatic) play key roles in rhizosphere ecology, pedogenesis, nutrient acquisition, allelochemical interactions, availability and detoxification of aluminium and pollutants, regulation of soil $\mathrm{pH}$, enzymatic activities, and in food-web interactions [1-9].

Carbohydrates represent dominant compounds of plant root exudates. They play an important role in the establishment and functioning of mycorrhizal symbioses and the stabilisation of heavy metals in soil [10-12]. Determination of soil carbohydrates is mostly related to the evaluation of the effect of land use change on soil organic matter status, particularly in terms of microbial transformation [13-15].

While there is little knowledge on occurrence of vitamins in soil, vitamins are known to play a number of important roles in plants including resistance to pathogens, plantmicrobe symbioses, microbial growth stimulation, and stimulation of organic pollutant degradation [16-19].

\section{Organic Acids in Soil}

2.1. Aliphatic Organic Acids. A wide range of organic acids has been found in soil. These include aliphatic acids such as acetic, citric, isocitric, fumaric, tartaric, oxalic, formic, lactic, malic, malonic, butyric, succinic, trans-aconitic, propionic, adipic and glycolic acids, and cyclic and aromatic acids such as benzoic, phenylacetic, shikimic, phthalic, ferulic, syringic, $p$-coumaric, vanillic, $p$-hydroxybenzoic, $m$-hydroxybenzoic, benzoic, caffeic, protocatechuic, gallic, gentisic, sinapic, rosmarinic, and transcinnamic acids [3, 20-33].

Knowledge of the behaviour of aliphatic organic acids in soil in terms of nutrient acquisition by plants, microbial degradation and adsorption, their role in pedogenesis and in Al detoxification, extraction, and analysis was reviewed by Jones [1], Jones et al. [2], and Van Hees et al. [34]. Separation of low molecular weight organic acid-metal complexes by HPLC was reviewed by Collins [35]. Organic acids were reported to form $4 \%$ of dissolved organic carbon (DOC) and up to $27 \%$ of acidity in mor layers of coniferous forests 
$[36,37]$. Individual aliphatic organic acids occur in soils from different ecosystems in concentrations up to $6000 \mu \mathrm{M}$ and within individual ecosystems, and the broadest spectrum of these acids was found in forest soils (Table 1).

Concentrations of aliphatic organic acids commonly decrease with soil depth, except in the case of some ecosystems such as those containing podzolized soils, where organic acids (e.g., formic acid) reportedly increased in concentration with depth [38]. Of the individual organic acids, fumaric acid was present in higher concentrations in mineral horizons of alkaline soils [45], while citric acid was reported in concentrations of between 20 and $1000 \mu \mathrm{M}$ in upper soil layers $[21,34,38,46]$. Citric acid played the most important role in terms of buffering capacity [24].

Organic acids are involved in the formation of complexes of $\mathrm{Al}$ and $\mathrm{Fe}$. The amount of complexed $\mathrm{Al}$ and $\mathrm{Fe}$ declines with soil depth [47]. Different organic acids play a role in the formation of complexes of $\mathrm{Al}$ and $\mathrm{Fe}$ within soil profiles. For example, citric acid has been reported as the most important complexing agent in $\mathrm{O}$ and $\mathrm{E}$ horizons, whereas oxalic acid is reported to play the most significant role in horizon B [47]. Citric, oxalic, and malic acids are thought to be particularly important in rhizosphere ecology and pedogenesis $[2,5,6]$.

The primary production rate of organic acids in different types of soils was predicted to be within the range of between $<1$ and $1250 \mathrm{nmol} / \mathrm{g}$ soil/d [6]. Acetic and formic acids increased in concentration with decomposition of wood chips during a mycoremediation process [48]. Low molecular weight organic acids are thought to be responsible for minimizing crop damage by the root-knot nematode Meloidogyne incognita (Kofoid and White (Chitwood)) [49]. Production of gluconic acid by rhizosphere soil bacteria presents an efficient strategy to avoid protozoan grazing. Gluconic acid was shown to cause encystment or death of protozoa [9]. Succinic acid decreased the growth and conidial germination of Fusarium oxysporum f. sp. niveum [50], while propionic, acetic, lactic, malic, and citric acids were all demonstrated to have significant antibacterial effects [51].

Organic acids were found to increase the activity of acid phosphomonoesterase in soil at low concentrations $(<1 \mu \mathrm{mol} / \mathrm{g})$, whereas higher concentrations $(>5 \mu \mathrm{mol} / \mathrm{g})$ of citric, oxalic, malic, and tartaric acid inhibited this activity [52]. Organic acids also act as adsorbents of acid phosphomonoesterase [4] from minerals and colloids (desorption by up to ca. 60\%). This indicates the changes in behaviour of acid phosphomonoesterase in the rhizosphere, where organic acids are released from plant roots, compared to bulk soil. Organic acids in soil are produced by plant root exudation and by activity of soil microorganisms. Phosphatesolubilizing bacteria (Bacillus, Rhodococcus, Arthrobacter, Serratia, Chryseobacterium, Delftia, Gordonia, and Phyllobacterium) which increase P-uptake by plants were reported to produce aliphatic organic acids such as citric, gluconic, lactic, propionic, and succinic acids [53].

Average respiration rates of organic acids (oxalate, citrate) were reported to be around $209 \mathrm{nmol} / \mathrm{g}$ soil/d, and respiration of organic acids increased with soil depth $[6,39]$. Van Hees et al. [21] and Ström et al. [54] reported rapid degradation of citric, malic, and oxalic acid in most soils. In some cases, organic acid degradation may be inhibited by complexation with $\mathrm{Ca}$ (oxalate in calcareous soils); degradation of individual organic acids may also differ between rhizosphere and bulk soil [39, 54]. Forest soils differ in their abilities to anaerobically consume organic acids such as oxalate. The addition of electron donors (acetate, glucose, vanillate, or hydrogen) or acceptors (nitrate or sulphate) did not affect anaerobic consumption of oxalate, whereas $\mathrm{CO}_{2}$ or bicarbonate totally repressed it [55].

There is a paucity of literature on organic acid enantiomers, but what does exist points to the need for urgent study. Liao et al. [25] identified D-tartaric acid in concentrations up to $6 \mu \mathrm{g} / \mathrm{g}$ in the rhizosphere of Lactuca sativa L., which, along with L-citric acid, formed the dominant organic acid. A recent review has highlighted the potential importance of future research in this area [56].

\subsubsection{Role of Aliphatic Organic Acids in Soil Decontamination.} Organic acids play an important role in the phytoremediation of polluted soils and in the availability of heavy metals and organic compounds. Mobilisation of polycyclic aromatic hydrocarbons (PAHs) such as pyrene or phenanthrene by organic acids (citric, oxalic, tartaric, lactic, or acetic) is dependent on the type of organic acid, $\mathrm{pH}$, and soil organic matter content $[8,57]$. For example, citric acid has been reported to be efficient in pyrene and phenanthrene extraction [8, 57]. Lower extractability of PAHs was found in soils of higher organic matter content, while adsorption of pyrene in the presence of organic acids decreased with increasing $\mathrm{pH}$. Citric and malic acids inhibited adsorption of chemotherapeutics in soil. Soil $\mathrm{pH}$, surface properties, and competitive adsorption of other cations affected this process [58].

Introduction of Bacillus thuringiensis $\left(\mathrm{B}_{t}\right)$ to soil, as a result of rapid planting of $\mathrm{B}_{t}$-transformed crops, may cause hazards for soil ecosystems; thus, the factors affecting its mobility need to be determined. Organic acids (citric, oxalic, and acetic) are one of the factors affecting mobility of $\mathrm{B}_{t}$ toxin in soil. Fu et al. [59] reported decreased adsorption of $\mathrm{B}_{t}$ toxin by minerals such as kaolinite, goethite, and silicon dioxide due to low concentrations of organic acids, whereas high concentrations of these acids promoted adsorption of the toxin. Increasing concentrations of oxalate and citrate inhibited adsorption of $\mathrm{B}_{t}$ toxin by montmorillonite.

Organic acids such as citric and tartaric acids were found to reduce $\mathrm{Cr}(\mathrm{VI})$ to $\mathrm{Cr}(\mathrm{III})$ in the soil [60] and to affect mobility of heavy metals due to their desorption, complexation, and precipitation. Dissolution of minerals in fly ash from smelters allowed conversion of heavy metals to their mobile forms [61-64]. Cu phytoextraction by Nicotiana tabacum L. was enhanced by citrate, whereas $\mathrm{Pb}$ phytoextraction was not stimulated by aliphatic organic acids, probably due to the rate of degradation of organic acids in soil, which is reported to be high for metals of low mobility and bioavailability [65].

Generally, citric acid is the most effective in terms of desorption of different heavy metals, followed by malic > acetic $>$ tartaric $>$ oxalic acid $\left(\mathrm{Cu}, \mathrm{Hg}, \mathrm{Pb}, \mathrm{Cd}, \mathrm{Zn}\right.$, and $\left.{ }^{137} \mathrm{Cs}\right)$ [66-73]. Schwab et al. [72] found citric acid to be the most 


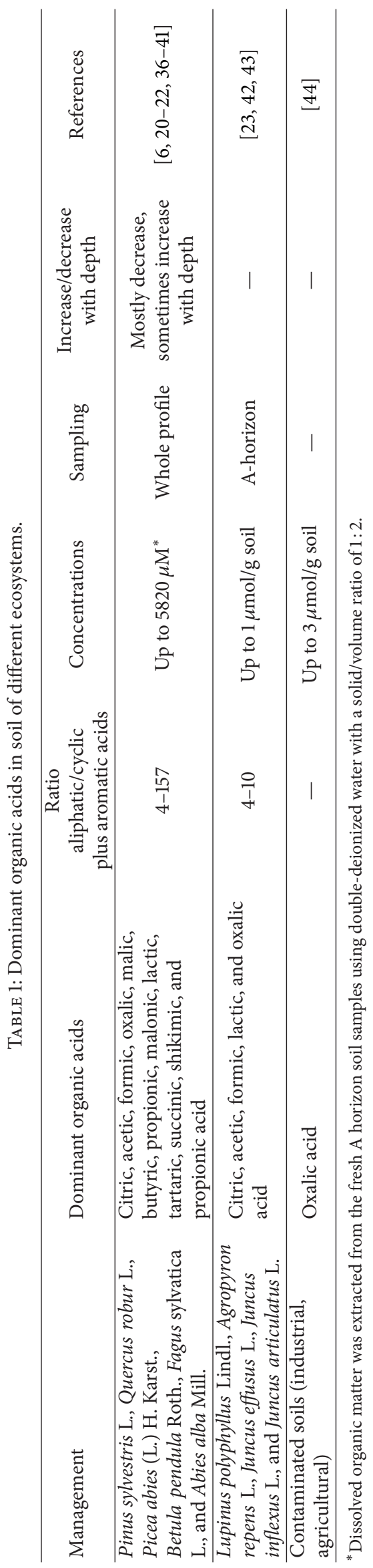


efficient in desorption of $\mathrm{Zn}$ and $\mathrm{Cd}$ in sandy loam, but it had little impact on $\mathrm{Pb}$ movement. Desorption of heavy metals in soil by organic acids depends on the concentration and degradability of the organic acids, $\mathrm{pH}$, and concentration of competing cations such as $\mathrm{Ca}^{2+}[61,62,74]$. Effective mobilisation of $\mathrm{Zn}$ in soil due to formation of citrate- $\mathrm{Zn}$ complexes was reported by Lombnæs et al. [62]. Citric acid rapidly degrades, even in heavy metal-polluted soils, with $20 \%$ degradation between 1 and 4 days being reported by Wen et al. [74]. Fast degradation of organic acids in soil leads to low migration $[6,54]$. On the other hand, complexation of organic acids with $\mathrm{Al}$ slightly decreases their degradation [5]. Metal complexes of organic acids differ in their microbial degradability, with higher degradation for citrate-metal complexes compared to oxalate-metal complexes [68].

Huang et al. [75] reported a stimulating effect of low molecular weight organic acids for $\mathrm{Cd}$ and $\mathrm{Pb}$ adsorption by goethite and montmorillonite, but only at low concentrations. At higher concentrations of these acids, decreased heavy metal adsorption was recorded. While citric and tartaric acids enhanced desorption of $\mathrm{Cu}$ in soil, oxalic acid was effective in desorption of $\mathrm{Cu}$ and $\mathrm{Cd}$ [61]. The mechanism of desorption was explained as competition in complexation, adsorption, and precipitation. Gao et al. [76] reported desorption of $\mathrm{Cd}$ and $\mathrm{Cu}$ by citric and tartaric acids, especially at higher concentrations. Low concentrations of these acids inhibited desorption.

Organic acids appeared to be efficient in the release of ${ }^{137} \mathrm{Cs}$ from contaminated soils, efficiency being in the order citric $>$ tartaric $>$ oxalic $>$ succinic $>$ acetic acid [73]. Desorption occurs in two phases: fast and slow. The fast stage of desorption corresponds with the interaction of organic acids with the surface of clay minerals, whereas the slow stage (occurring over a much longer period) is attributed to inter- and intraparticle diffusion. Debela et al. [64] reported the release of $\mathrm{Pb}$ from pyromorphite $\left[\mathrm{Pb}_{5}\left(\mathrm{PO}_{4}\right)_{3} \mathrm{Cl}\right]$ by citric, malic, acetic, and oxalic acids. Interestingly, low concentrations of organic acids may increase adsorption of heavy metals in soil [77].

2.2. Cyclic and Aromatic Organic Acids in Soil. Cyclic and aromatic organic acids play a range of roles in soils, including allelopathic interactions, inhibition of microbial growth, and weathering of minerals $[78,79]$. Some aromatic acids in soil solution may also be used to distinguish between vegetation types in forests [40]. Asao et al. [3] reported that benzoic, $m$ - and $p$-hydroxybenzoic, vanillic, and adipic acids inhibited plant growth. Of these, benzoic acid was the strongest inhibitor. Ferulic acid is released from plant roots and from decomposition of soil organic matter and may be involved in allelopathic interactions. Caspersen et al. [80] reported the presence of bacteria in commercial hydroponic Lactuca sativa L. culture which were able to ameliorate the toxic effects of ferulic acid.

Aromatic acids (salicylic and phthalic) are adsorbed by soils of different charges, and the adsorption of these acids differs significantly according to the soil tested. Adsorption of aromatic and aliphatic acids decreased the zeta potential of soils and oxides [81, 82]. Adsorption of salicylate in soil appeared to be significantly lower compared to citrate (Freundlich constant for adsorption $\mathrm{K}_{F} 0.499$ versus 0.107 ) [69]. Adsorption of gallic acid was not influenced by soil depth or land use [26]. Gallic acid decreased the amount of total inorganic nitrogen extractable from soil by $\mathrm{KCl}$ and increased solubility of $\mathrm{Ca}$ and $\mathrm{Mn}$ through formation of metal-gallic acid complexes and redox reactions. However, gallic acid did not affect extraction of total soluble-N.

Inderjit and Bhowmik [27] reported sorption of benzoic acid in soil which increased with its concentration, with a nonlinear adsorption isotherm. The authors reported sorption to be sufficiently strong to protect plants from phytotoxic effects of this compound and to be $\mathrm{pH}$-dependent. Benzoic acid is reversibly adsorbed to soil particles by van der Waal or hydrogen bonding and can be released to soil solution due to decreasing strength of the soil solution or presence of competing ions [83]. Evans Jr. [84] reported decreasing degradation of phthalic acid with depth in forest soil. Shikimic acid was detected in mor layer extracts in concentrations of $12 \mu \mathrm{M}$ [37]. Shikimic acid (even in a large quantity) did not affect decomposition of citrate, malate, and oxalate in agricultural soils [85] and had a low effect on sorption of these acids. Oburger et al. [85] reported the half-life for shikimic acid in different soils to be within a range from 0.6 to $8.6 \mathrm{~h}$. Caffeic acid inhibited growth of Frankia isolates [79], while gentisic, o-hydroxyphenylacetic, and vanillic acid were less inhibitory.

\subsubsection{Role of Cyclic and Aromatic Organic Acids in Availability} of Heavy Metals. Cyclic and aromatic organic acids affect availability of heavy metals in soils. Whereas salicylic acid decreased availability of $\mathrm{Pb}$, the presence of phthalic or salicylic acid increased the capacity of exchangeable Al. In some of the tested soils, salicylic acid decreased the capacity due to its lower adsorption and its formation of soluble Alsalicylate complexes $[69,82]$. The ability of aromatic acids to mobilize $\mathrm{Al}$ is lower compared to a range of aliphatic organic acids (citric, oxalic, malonic, malic, and tartaric) but was higher than in the cases of lactic or maleic acid $[86,87]$. Mobilisation of Al by salicylic acid was decreased by increasing $\mathrm{pH}$.

Some aromatic acids, such as gallic acid, are efficient in extraction of heavy metals $(\mathrm{Cd}, \mathrm{Cu}, \mathrm{Zn}$, and $\mathrm{Ni}$ ) [70]. Weathering of minerals (e.g., labradorite $\left((\mathrm{Ca}, \mathrm{Na})(\mathrm{Si}, \mathrm{Al})_{4} \mathrm{O}_{8}\right)$ or microcline $\left(\mathrm{KAlSi}_{3} \mathrm{O}_{8}\right)$ ) by formation of Al-organic complexes by salicylic acid was reported by Huang and Keller [78]. Salicylic and phthalic acid release $\mathrm{Cu}$ from chalcopyrite $\left(\mathrm{CuFeS}_{2}\right)$ and release $\mathrm{Ca}$ and $\mathrm{P}$ from apatite $\left(\mathrm{Ca}_{5}\left(\mathrm{PO}_{4}\right)_{2.82}(\mathrm{FeClOH})_{1.54}\right)$ [88]. Salicylic and phthalic acid are less efficient in release of yttrium from phosphate minerals (apatite, monazite) than citrate; phthalate efficiency is comparable to oxalate [89].

\section{Carbohydrates in Soil}

Glucose, galactosamine, fructose, rhamnose, arabinose, fucose, glucosamine, galactose, xylose, mannose, ribose, 
mannosamine, muramic, galacturonic, and glucuronic acids have all been identified in soil [15, 28, 90-96]. Tian et al. [60] reported ca. $30 \%$ of DOC in arable soils was formed by carbohydrates, representing 4-7\% of total organic carbon [97]. The annual flux of carbohydrates infiltrating mineral soil of Picea abies (L.) H. Karst. stands was assessed by Guggenberger et al. [98] to be ca. $70 \mathrm{~kg} / \mathrm{ha} / \mathrm{y}$. Sugars as well as phenolic compounds are chemoattractants of rhizobacteria $[99,100]$. Carbohydrates alleviate negative effects of wood ash on enchytraeid growth and abundance, possibly by correcting an imbalance in the bacteria: fungi ratio, which is increased by addition of wood ash [101]. Glucuronic, galacturonic, and alginic acids (main constituents of bacterial exopolymeric substances) play a role in stabilisation of heavy metals such as $\mathrm{Cr}$ (VI) in soil under acidic or slightly alkaline conditions [12]. The ratio of carbohydrate $\mathrm{C} /$ polyphenol $\mathrm{C}$ in soil hydrolysates is used as an indicator of soil organic matter quality [102], and the ratio of total carbohydrates $/ \mathrm{K}_{2} \mathrm{SO}_{4}$ extractable total $\mathrm{N}$ appears to be a good predictor of $\mathrm{N}$ mineralisation and microbial biomass $\mathrm{N}$ [103].

Adsorption of carbohydrates, such as glucose or fructose, on alumina interfaces is characterised by an adsorption isotherm of a typical L-type, and an adsorption mechanism based on dipolar interaction has been suggested [90]. The adsorption was $\mathrm{pH}$ dependent and was affected by anions $\left(\mathrm{Cl}^{-}, \mathrm{SO}_{4}^{2-}\right.$, and $\left.\mathrm{PO}_{4}^{3-}\right)$ and cations; fructose appeared to be better adsorbed than glucose. Pentoses (arabinose and xylose) are not synthesised by microorganisms and are constituents of plant biomass. On the other hand, galactose, mannose, rhamnose, and fucose are of microbial origin $[14,104]$ and up to ca. $16 \mathrm{mg} / \mathrm{g}$ soil organic carbon from a range of different soils was ascribed to microbial sugars [105]. According to Oades [106], the ratio of galactose plus mannose/arabinose plus xylose is low $(<0.5)$ for plantderived sugars and high $(>2)$ for microbial sugars.

Amino sugars represent major constituents of microbial cell walls and hydrolysable soil organic matter. Free amino sugars represent a small part of the dissolved organic $\mathrm{C}$ and $\mathrm{N}$ pools [107]. Muramic acid, glucosamine, mannosamine, and galactosamine may be used as an indicator of microbial origin of soil organic matter [108, 109]. Glaser et al. [110] reported that total amino sugar and muramic acid in soil microbial biomass varied between 1 and $27 \mathrm{mg} / \mathrm{kg}$ soil, while microbial biomass made a negligible contribution to total amino sugar concentration in soil. Glucosamine and galactosamine were found in the highest concentrations in different horizons of forest and prairie soils (up to $5200 \mathrm{mg} / \mathrm{kg}$ soil) $[108,109]$.

Carbohydrates from soil microbial biomass were reported by Joergensen et al. [111] to account for $17 \%$ of total carbohydrate $\mathrm{C}$, and the content of microbial biomass carbohydrates correlated well with microbial biomass C [112]. Carbohydrates are extracted from soil using cold or hot water, $0.5 \mathrm{M} \mathrm{K}_{2} \mathrm{SO}_{4}, 0.25 \mathrm{M} \mathrm{H}_{2} \mathrm{SO}_{4}, 1 \mathrm{M} \mathrm{HCl}, 0.5 \mathrm{M} \mathrm{NaOH}$, or $4 \mathrm{M}$ trifluoroacetic acid [13,105, 111, 113, 114]. Adesodun et al. [115] and Ball et al. [13] reported extraction of the lowest carbohydrate fraction (3\%) using cold water, $10 \%$ by hot water, $12 \%$ by $1 \mathrm{M} \mathrm{HCl}$, and $75 \%$ by $0.5 \mathrm{M} \mathrm{NaOH}$.
3.1. The Role of Carbohydrates in Aggregation. Mineralorganic associations represent a large amount of carbon in terrestrial ecosystems; these associations have a high abundance of microbially derived carbohydrates [116]. Plant carbohydrates depend on texture type, being higher for loamy sand than silt loam [117]. Carbohydrates play an important role in the formation of stable aggregates [118]. Fungi increase aggregate stability, due to a supply of extracellular polysaccharides [119]. On the other hand, Adesodun et al. [115] reported that aggregate stability correlated very poorly with carbohydrates fractions. Aggregate stability seems to better correlate with carbohydrates in hot water or dilute acid extracts, indicating suitability of these types of extracts to indicate changes in soil due to land use change [120].

Microaggregates $(20-53 \mu \mathrm{m})$ had a higher ratio of mannose plus galactose/arabinose plus xylose than other aggregate fraction of larger sizes up to $>212 \mu \mathrm{m}$ (macro- and meso-), indicating the importance of microbial processes. Solomon et al. [14] reported an increase of neutral sugars and uronic acids in particle size fractions, in the order silt $<$ coarse sand $<$ fine sand $<$ clay. Soil organic matter in nanosize structures isolated from a clay fraction accumulated carbohydrates between groups of other compounds (Nheterocyclics, peptides, and alkyl aromatics) [121]. Puget et al. [122] found increasing carbohydrates with aggregate size, clay, and silt fractions within stable aggregates.

3.2. Carbohydrates in Different Soil Types and Depths. Soil type has an impact upon sugar synthesis by microorganisms, reflecting microbial biodiversity and varied ecophysiology between soils. Derrien et al. [123] quantified sugar synthesis in soil from ${ }^{13} \mathrm{C}$ labelled substrates using compound-specific isotope ratio mass spectrometry. The authors reported that the quality of added substrate (mono- and polysaccharide or amino acid) had little effect upon sugar production in soil.

The concentration of carbohydrates generally decreases with soil depth $[105,124]$. Carbohydrate content decreased from litter to soil organic matter and aggregates with incorporation of soil [125]. Carbohydrates can accumulate in horizons with strongly humified organic matter probably due to the toxic effect of adsorption to some oxides or hydroxide minerals, especially those with aluminium content. Minerals such as ferrihydrite and aluminium hydroxide reduced carbohydrate decomposition by $15-50 \%$ [124].

Osono et al. [126] reported a higher content of soluble carbohydrates in bleached litter colonised by Clitocybe sp. than in nonbleached litter. Carbohydrates are amongst the more rapidly degraded compounds of plant litter, resulting in organic matter being more enriched in lignin-derived compounds [127]. The ratio of selected hexoses to pentoses in needles was 1-15 times lower compared to decomposing litter [128].

Rumpel et al. [129] evaluated the effect of soil type on carbohydrate content and found that carbohydrate content was generally higher in Cambisol than Podzol. Sugars were enriched in mineral-bound fractions of organic matter, often with microbial monosaccharides. On the other hand, bulk 
soil was characterised by higher contributions of plantderived sugars. The type of extractant has an effect on the proportion of carbohydrates in total organic $\mathrm{C}$ within a profile. Water-soluble carbohydrates are generally not proportional to the total organic carbon content in soil [130]. The ratio of hydrolysable carbohydrate $\mathrm{C} /$ total organic $\mathrm{C}$ increased with soil depth, with an increasing importance of cellulosic polysaccharides in the B horizon. In hot water extracts, the ratio was similar throughout the whole profile $[131,132]$. Sugars (other than cellulosic) were maintained at a relatively constant level within the soil profile $(12-15 \%$ of organic carbon).

Generally, glucose was found in the highest concentrations in the upper humus layer [131]. The importance of microbially derived sugars increased with soil depth [105]. The ratio of mannose plus galactose/xylose plus arabinose increased from the litter layer to the $\mathrm{H}$ horizon, indicating the increasing importance of microbially derived sugars. The type of extractant used has an effect on the ratio of galactose plus mannose/xylose plus arabinose. Hot-water extraction was 1-1.6 compared to a $\mathrm{NaOH}$ extraction, with the ratio 0.4-0.7 indicating a higher microbial contribution in hotwater extracts [13]. Verchot et al. [118] reported decreased concentrations of carbohydrates in soil with depth; arabinose and mannose were the most abundant sugars within aggregate fractions (micro-, meso-, macro-, and bulk soil). Amino sugars were also found to decrease downward in the profiles [133].

A high level of water (in Bg horizon) negatively affects the proportion of amino sugars within the total organic carbon. Enhanced drying of soil decreased the contribution of plant and microbial sugars to soil organic matter in the $\mathrm{O}$ and $\mathrm{A}$ horizons even though the sugar content of the original plant material increased with drying [105]. However, the concentration of mannitol and trehalose (stress-induced fungal metabolites) increased at low soil moisture [134].

3.3. The Effect of Land Use on Soil Carbohydrates. The concentration of soluble sugars in soils from different ecosystems changes over the course of the vegetative season $[113,134]$ and is affected by the type of plant coverage, soil properties, and microbial activity. The concentration of pentoses during a growing season corresponded with litterfall, ground grass cutting in forest sites, drying of grass in grasslands, and harvest in agroecosystems [135].

Management of ecosystems may affect carbohydrate quantity, quality, and distribution within soils $[13,14,136$, 137]. Generally, management of soil has no effect on the occurrence of dominant carbohydrates in soil hydrolysates (Table 2). Carbohydrate content in soils will increase in a number of situations, including integrated crop-livestock systems, cultivated fields compared to tropical woodlands, establishment of pasture on acid savanna soils, arable compared to fallow sites, manuring, application of organic wastes such as poultry manure or composts in saline soils, larvae (Trpula paludosa), addition of Aspergillus niger with Beta vulgaris L. wastes, inoculation with Bacillus cereus, mixing of mineral soil with the litter layer, forests compared to pastures or cropland, elevated $\mathrm{CO}_{2}$, reduction of fungicides, mycorrhizal inoculation, and the addition of Beta vulgaris $\mathrm{L}$. or rock phosphate [14, 60, 98, 103, 113, 120, 138-148]. The type of management of arable land influences distribution of soil carbohydrates, being more uniform within depth in ploughed compared to drilled soils [13].

Manure application, crop rotation, and avoiding tillage for 6 years all increased amino sugar content in soil [120, 138]. Amino sugar content was at its highest on plots with continuous Zea mays L. monoculture (up to $1317 \mathrm{mg} / \mathrm{kg}$ ) compared to a Zea mays L.-Glycine max (L.) Merr. rotation field [158]. Carbohydrates (especially glucose and xylose) are dominant components of dung $[120,138]$ and are thought to contribute significantly to carbon stock and aggregate stability in manured soils, replacing the existing pool. A maximum of $60 \%$ of dung-derived C was found as carbohydrates after 56 days incubation. Management of land has effects on the utilisation of dominant compounds in water-soluble root exudates. For example, nontilled plots had higher microbial utilisation of carboxylic acids and lower utilisation of amino acids and carbohydrates compared to conventionally tilled or rotatory-tilled soils [159]. Stevenson et al. [160] reported higher utilisation of carbohydrates and amino acids and lower utilisation of carboxylic acids in soils of pasture relative to forest soils.

In terms of other treatments, UV-B radiation reduced extractability of carbohydrates from leaf litter of Quercus robur L., thus changing litter carbon source availability for soil microorganisms [161]. The ratio of rhamnose plus fucose/xylose plus arabinose increased on the forest floor and in the coarse fraction of topsoil after forest dieback [162]. The ratio of mannose plus galactose/xylose plus arabinose was higher in C-depleted than fertilised plots with the highest value in fine particles [163].

Change in land use (e.g., pasture to arable land) also causes a new equilibrium for soil carbohydrates, established after 14 and 56 years [139]. Carbohydrates occurred in higher concentration in macroaggregates than microaggregates, and the ratio of distribution of carbohydrates between macroaggregates and microaggregates did not change over 110 years. No effect of arable soil fertilisation (organic versus mineral) on the occurrence of sugars (rhamnose, xylose, glucose, mannose, arabinose, and galactose) in soil hydrolysates was reported by Lima et al. [28]. Eleven years after liming of Picea abies (L.) H. Karst. stands, no significant changes in the carbohydrate fraction were found by Rosenberg et al. [164].

Soil carbohydrate levels have also been reported to decrease during boreal forest succession, root exclusion, grazing of semiarid shrubland, conversion of pasture to cropland, and during conversion of forests on sandy spodosols to Zea mays L. cropping [15, 97, 136, 137, 165]. Amino sugar content decreases with afforestation, cultivation of plots related to grassland, and during clear-cutting of forest related to cultivated sites $[93,97]$. The application of fungicides may significantly change concentrations of some sugars in soil (e.g., mannose). Earthworms reduced the concentration of xylose and glucose, suggesting accelerated turnover of plant material in the soil [136]. 


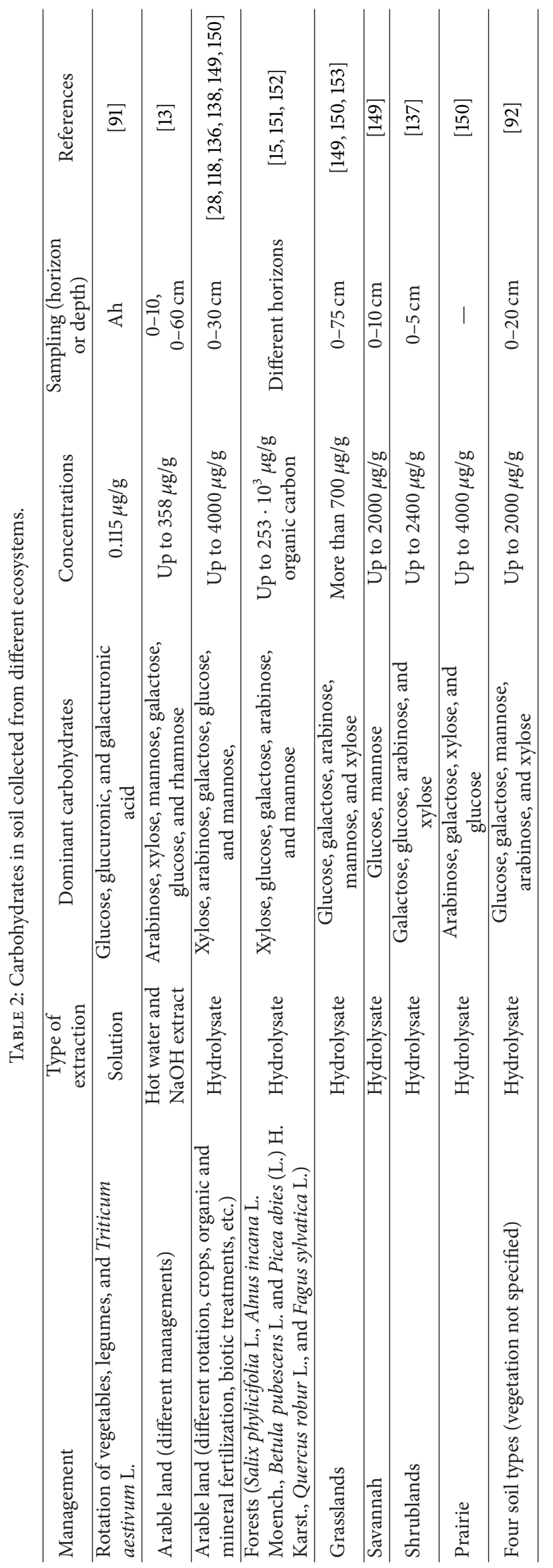


TABLE 3: Vitamins in plant root exudates.

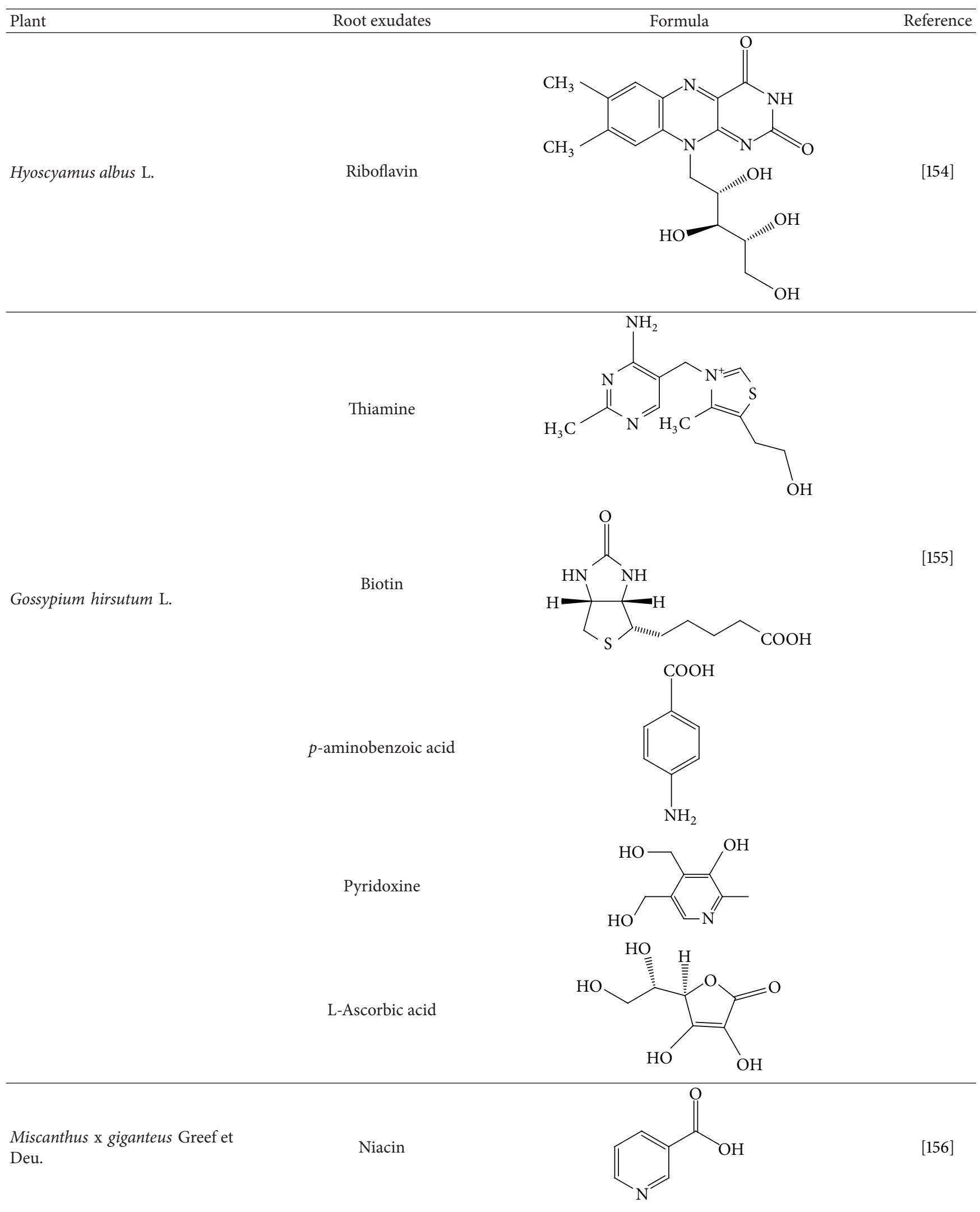


TABLE 3: Continued.

Plant Root exudates

\section{Vitamins in Soil}

Knowledge of the quantity of vitamins in soils of different ecosystems is poor. Sulochana [155] found pyridoxine, thiamine, $p$-aminobenzoic acid, and traces of biotin in soil. Barrera-Bassols et al. [166] suggested that Quercus robur L. litter could contain high vitamin content, but experimental proof is currently lacking. Soil algae produce vitamin signals (lumichrome and riboflavin) that act as agonists within bacterial communities through quorum sensing [167]. Vitamins are also known to act as attractants to Caenorhabditis elegans.

Vitamins may be important in the decontamination of polluted soils and were reported to stimulate PAHs degradation [19] and attenuation of alkanes in oil-polluted desert soil $[16,19]$. Vitamins added to soil increased the rate of degradation of 2,4,6-trinitrotoluene (TNT) [168]. The addition of vitamins $B_{1}+B_{6}+B_{12}$ enhanced the growth of fungi in the presence of phenol [169], while the addition of a vitamin solution containing biotin, folic acid, riboflavin, niacin, and thioctic acid increased phenolic degradation by between 7 and $16 \%$ [170]. Minor adsorption of vitamin $B_{12}$ on kaolinite clay and sand, with no detectable adsorption to alumina, was reported by Hashsham and Freedman [171].

Vitamins (riboflavin, vitamin $\mathrm{B}_{12}$, niacin, thiamine, ascorbic and pantothenic acid, $p$-aminobenzoic acid, biotin, $\beta$-carotene, pyridoxine, and tocopherol) $[154,172-174]$ enter soil from different sources including root exudation (Table 3 ), plant biomass, and bacterial production [154, 172, 174-177]. For example, the distribution of vitamin $\mathrm{E}(\alpha-, \beta$-, and $\gamma$ tocopherol) in Picea abies (L.) H. Karst. was reported by Franzen et al. [178]. While $\alpha$-tocopherol was found in all organs, $\beta$ - and $\gamma$-tocopherol were restricted to seedlings and seeds. Phosphate-solubilising bacteria, azotobacters, and rhizobia are significant producers of vitamins [172, 174, 179, 180]. Hodson et al. [180] isolated the soil bacterium Mesorhizobium loti, whose genome sequence is known to support growth of the vitamin $\mathrm{B}_{12}$ auxotroph Lobomonas rostrata. Application of some insecticides may inhibit microbial production of vitamins in soil by bacteria such as Azospirillum brasilense [181].

\section{Conclusions}

Aliphatic, cyclic, and aromatic organic acids play an important role in soil and rhizosphere ecology, as well as in decontamination of polluted sites. Despite much work on the occurrence and behaviour of organic acids in soil, current knowledge is mostly restricted to their L-enantiomers. In future research, determination of the occurrence and role of
D-enantiomers of organic acids in soil and rhizodeposition should become a significant focus, particularly relating to their potential in allelopathic interactions, decontamination of polluted sites, and in terms of their roles in plants suitable for phytoremediation purposes. Carbohydrates represent an abundant group within soil organic matter, serving as an indicator of the quality of soil organic matter and of land use changes. Despite the existence of a broad literature on soil carbohydrates and their fractionation within soils across many ecosystems, there still remains a paucity of research on the effects of environmental factors, especially altered soil water content, on qualitative and quantitative changes in soil carbohydrates. Vitamins play an important role in biochemical soil processes and decontamination of polluted sites. More research is needed on their occurrence and behaviour in soil.

\section{Conflict of Interests}

The authors declare that there is no conflict of interests regarding the publication of this paper.

\section{Acknowledgments}

This text was created within the framework of the Grants TA02020867, QJ1320040, and the IGA Project 55/2013.

\section{References}

[1] D. L. Jones, "Organic acids in the rhizosphere-a critical review," Plant and Soil, vol. 205, no. 1, pp. 25-44, 1998.

[2] D. L. Jones, T. Eldhuset, H. A. De Wit, and B. Swensen, "Aluminium effects on organic acid mineralization in a Norway spruce forest soil," Soil Biology and Biochemistry, vol. 33, no. 9, pp. 1259-1267, 2001.

[3] T. Asao, K. Hasegawa, Y. Sueda et al., "Autotoxicity of root exudates from taro," Scientia Horticulturae, vol. 97, no. 3-4, pp. 389-396, 2003.

[4] Q. Huang, Z. Zhao, and W. Chen, "Effects of several lowmolecular weight organic acids and phosphate on the adsorption of acid phosphatase by soil colloids and minerals," Chemosphere, vol. 52, no. 3, pp. 571-579, 2003.

[5] A. M. Fransson, S. Vinogradoff, D. L. Godbold, P. A. W. Van Hees, and D. L. Jones, "Aluminum complexation suppresses citrate uptake by acid forest soil microorganisms," Soil Biology and Biochemistry, vol. 36, no. 2, pp. 353-357, 2004.

[6] P. A. W. Van Hees, D. L. Jones, L. Nyberg, S. J. M. Holmström, D. L. Godbold, and U. S. Lundström, "Modelling low molecular weight organic acid dynamics in forest soils," Soil Biology and Biochemistry, vol. 37, no. 3, pp. 517-531, 2005. 
[7] Z.-A. Li, B. Zou, H.-P. Xia, Y.-Z. Ding, W.-N. Tan, and S.-L. Fu, "Role of low-molecule-weight organic acids and their salts in regulating soil ph1 1 project supported by the national natural science foundation of china (Nos. 30670393 and 30630015), the knowledge innovation program of the chinese academy of sciences (No. KSCX2-SW-133), the science and technology planning of guangdong province (No. 2006A36703004)," Pedosphere, vol. 18, no. 2, pp. 137-148, 2008.

[8] C. An, G. Huang, H. Yu, J. Wei, W. Chen, and G. Li, "Effect of short-chain organic acids and $\mathrm{pH}$ on the behaviors of pyrene in soil-water system," Chemosphere, vol. 81, no. 11, pp. 1423-1429, 2010.

[9] W. Gómez, L. Buela, L. T. Castro, V. Chaparro, M. M. Ball, and L. A. Yarzábal, "Evidence for gluconic acid production by Enterobacter intermedium as an efficient strategy to avoid protozoan grazing," Soil Biology and Biochemistry, vol. 42, no. 5, pp. 822-830, 2010.

[10] M. S. Aulakh, R. Wassmann, C. Bueno, J. Kreuzwieser, and H. Rennenberg, "Characterization of root exudates at different growth stages of ten rice (Oryza sativa L.) cultivars," Plant Biology, vol. 3, no. 2, pp. 139-148, 2001.

[11] U. Nehls, N. Grunze, M. Willmann, M. Reich, and H. Küster, "Sugar for my honey: carbohydrate partitioning in ectomycorrhizal symbiosis," Phytochemistry, vol. 68, no. 1, pp. 82-91, 2007.

[12] C. Kantar, Z. Cetin, and H. Demiray, "In situ stabilization of chromium(VI) in polluted soils using organic ligands: the role of galacturonic, glucuronic and alginic acids," Journal of Hazardous Materials, vol. 159, no. 2-3, pp. 287-293, 2008.

[13] B. C. Ball, M. V. Cheshire, E. A. G. Robertson, and E. A. Hunter, "Carbohydrate composition in relation to structural stability, compactibility and plasticity of two soils in a long-term experiment," Soil and Tillage Research, vol. 39, no. 3-4, pp. 143160, 1996.

[14] D. Solomon, J. Lehmann, and W. Zech, "Land use effects on soil organic matter properties of chromic luvisols in semi-arid northern Tanzania: carbon, nitrogen, lignin and carbohydrates," Agriculture, Ecosystems and Environment, vol. 78, no. 3, pp. 203213, 2000.

[15] P. Merilä, M. Malmivaara-Lämsä, P. Spetz et al., "Soil organic matter quality as a link between microbial community structure and vegetation composition along a successional gradient in a boreal forest," Applied Soil Ecology, vol. 46, no. 2, pp. 259-267, 2010.

[16] S. S. Radwan and A. S. Al-Muteirie, "Vitamin requirements of hydrocarbon-utilizing soil bacteria," Microbiological Research, vol. 155, no. 4, pp. 301-307, 2001.

[17] H. G. Pushpalatha, S. R. Mythrashree, R. Shetty et al., "Ability of vitamins to induce downy mildew disease resistance and growth promotion in pearl millet," Crop Protection, vol. 26, no. 11, pp. 1674-1681, 2007.

[18] M. E. Taga and G. C. Walker, "Sinorhizobium meliloti requires a cobalamin-dependent ribonucleotide reductase for symbiosis with its plant host," Molecular Plant-Microbe Interactions, vol. 23, no. 12, pp. 1643-1654, 2010.

[19] A. P. Jonsson and T. L. Östberg, "The effects of carbon sources and micronutrients in whey and fermented whey on the kinetics of phenanthrene biodegradation in diesel contaminated soil," Journal of Hazardous Materials, vol. 192, no. 3, pp. 1171-1177, 2011.

[20] Y. Shen, L. Ström, J.-Å. Jönsson, and G. Tyler, "Low-molecular organic acids in the rhizosphere soil solution of beech forest
(Fagus sylvatica L.) Cambisols determined by ion chromatography using supported liquid membrane enrichment technique," Soil Biology and Biochemistry, vol. 28, no. 9, pp. 1163-1169, 1996.

[21] P. A. W. Van Hees, D. L. Jones, and D. L. Godbold, "Biodegradation of low molecular weight organic acids in coniferous forest podzolic soils," Soil Biology and Biochemistry, vol. 34, no. 9, pp. 1261-1272, 2002.

[22] A. Sandnes, T. D. Eldhuset, and G. Wollebæk, "Organic acids in root exudates and soil solution of Norway spruce and silver birch," Soil Biology and Biochemistry, vol. 37, no. 2, pp. 259-269, 2005.

[23] R. Baziramakenga, R. R. Simard, and G. D. Leroux, "Determination of organic acids in soil extracts by ion chromatography," Soil Biology and Biochemistry, vol. 27, no. 3, pp. 349-356, 1995.

[24] A. Bergelin, P. A. W. Van Hees, O. Wahlberg, and U. S. Lundström, "The acid-base properties of high and low molecular weight organic acids in soil solutions of podzolic soils," Geoderma, vol. 94, no. 2-4, pp. 223-235, 2000.

[25] Y. C. Liao, S. W. C. Chien, M. C. Wang, Y. Shen, P. L. Hung, and $\mathrm{B}$. Das, "Effect of transpiration on $\mathrm{Pb}$ uptake by lettuce and on water soluble low molecular weight organic acids in rhizosphere," Chemosphere, vol. 65, no. 2, pp. 343-351, 2006.

[26] J. J. Halvorson, J. M. Gonzalez, A. E. Hagerman, and J. L. Smith, "Sorption of tannin and related phenolic compounds and effects on soluble-N in soil," Soil Biology and Biochemistry, vol. 41, no. 9, pp. 2002-2010, 2009.

[27] I. Inderjit and P. C. Bhowmik, "Sorption of benzoic acid onto soil colloids and its implications for allelopathy studies," Biology and Fertility of Soils, vol. 40, no. 5, pp. 345-348, 2004.

[28] D. L. D. Lima, S. M. Santos, H. W. Scherer et al., "Effects of organic and inorganic amendments on soil organic matter properties," Geoderma, vol. 150, no. 1-2, pp. 38-45, 2009.

[29] S. J. Grayston, D. Vaughan, and D. Jones, "Rhizosphere carbon flow in trees, in comparison with annual plants: the importance of root exudation and its impact on microbial activity and nutrient availability," Applied Soil Ecology, vol. 5, no. 1, pp. 2956, 1997.

[30] S. Mandal, "Allelopathic activity of Root Exudates from Leonurus sibiricus L. (Raktodrone)," Weed Biology and Management, vol. 1, no. 3, pp. 170-175, 2001.

[31] H. P. Bais, T. S. Walker, H. P. Schweizer, and J. M. Vivanco, "Root specific elicitation and antimicrobial activity of rosmarinic acid in hairy root cultures of Ocimum basilicum," Plant Physiology and Biochemistry, vol. 40, no. 11, pp. 983-995, 2002.

[32] K. Nambu, P. A. W. Van Hees, S. A. Essén, and U. S. Lundström, "Assessing centrifugation technique for obtaining soil solution with respect to leaching of low molecular mass organic acids from pine roots," Geoderma, vol. 127, no. 3-4, pp. 263-269, 2005.

[33] M. V. Medvedeva and A. S. Yakovlev, "Changes in the biochemical characteristics of soils in the impact zone of the Kostomuksha Ore-Dressing enterprise," Eurasian Soil Science, vol. 44, no. 2, pp. 211-216, 2011.

[34] P. A. W. Van Hees, D. L. Jones, R. Finlay, D. L. Godbold, and U. S. Lundström, "The carbon we do not see-the impact of low molecular weight compounds on carbon dynamics and respiration in forest soils: a review," Soil Biology and Biochemistry, vol. 37, no. 1, pp. 1-13, 2005.

[35] R. N. Collins, "Separation of low-molecular mass organic acidmetal complexes by high-performance liquid chromatography," Journal of Chromatography A, vol. 1059, no. 1-2, pp. 1-12, 2004. 
[36] P. A. W. van Hees, J. Dahlén, U. S. Lundström, H. Borén, and B. Allard, "Determination of low molecular weight organic acids in soil solution by HPLC," Talanta, vol. 48, no. 1, pp. 173-179, 1999.

[37] P. A. W. Van Hees, U. S. Lundström, and C.-M. Mörth, "Dissolution of microcline and labradorite in a forest $\mathrm{O}$ horizon extract: the effect of naturally occurring organic acids," Chemical Geology, vol. 189, no. 3-4, pp. 199-211, 2002.

[38] P. A. W. Van Hees, U. S. Lundström, and R. Giesler, "Low molecular weight organic acids and their Al-complexes in soil solution-composition, distribution and seasonal variation in three podzolized soils," Geoderma, vol. 94, no. 2-4, pp. 173-200, 2000.

[39] P. A. W. Van Hees, D. L. Jones, G. Jentschke, and D. L. Godbold, "Organic acid concentrations in soil solution: effects of young coniferous trees and ectomycorrhizal fungi," Soil Biology and Biochemistry, vol. 37, no. 4, pp. 771-776, 2005.

[40] D. Pizzeghello, A. Zanella, P. Carletti, and S. Nardi, "Chemical and biological characterization of dissolved organic matter from silver fir and beech forest soils," Chemosphere, vol. 65 , no. 2, pp. 190-200, 2006.

[41] S. J. M. Holmström, P. A. W. Van Hees, and U. S. Lundström, "Modelling of aluminium chemistry in soil solution of untreated and dolomite treated podzolic soil," Geoderma, vol. 127, no. 3-4, pp. 280-292, 2005.

[42] L. Weisskopf, R.-C. Le Bayon, F. Kohler et al., "Spatio-temporal dynamics of bacterial communities associated with two plant species differing in organic acid secretion: a one-year microcosm study on lupin and wheat," Soil Biology and Biochemistry, vol. 40, no. 7, pp. 1772-1780, 2008.

[43] S. Blossfeld, D. Gansert, B. Thiele, A. J. Kuhn, and R. Lösch, “The dynamics of oxygen concentration, $\mathrm{pH}$ value, and organic acids in the rhizosphere of Juncus spp," Soil Biology and Biochemistry, vol. 43, no. 6, pp. 1186-1197, 2011.

[44] W.-X. Ren, P.-J. Li, L. Zheng, S.-X. Fan, and V. A. Verhozina, "Effects of dissolved low molecular weight organic acids on oxidation of ferrous iron by Acidithiobacillus ferrooxidans," Journal of Hazardous Materials, vol. 162, no. 1, pp. 17-22, 2009.

[45] K. Nambu, P. A. W. van Hees, D. L. Jones, S. Vinogradoff, and U. S. Lundström, "Composition of organic solutes and respiration in soils derived from alkaline and non-alkaline parent materials," Geoderma, vol. 144, no. 3-4, pp. 468-477, 2008.

[46] M. Sulyok, M. Miró, G. Stingeder, and G. Koellensperger, "The potential of flow-through microdialysis for probing lowmolecular weight organic anions in rhizosphere soil solution," Analytica Chimica Acta, vol. 546, no. 1, pp. 1-10, 2005.

[47] P. A. W. van Hees and U. S. Lundström, "Equilibrium models of aluminium and iron complexation with different organic acids in soil solution," Geoderma, vol. 94, no. 1, pp. 199-219, 2005.

[48] B. Piškur, J. Zule, M. Piškur, D. Jurc, and F. Pohleven, "Fungal wood decay in the presence of fly ash as indicated by gravimetrics and by extractability of low molecular weight volatile organic acids," International Biodeterioration and Biodegradation, vol. 63, no. 5, pp. 594-599, 2009.

[49] R. G. McBride, R. L. Mikkelsen, and K. R. Barker, "The role of low molecular weight organic acids from decomposing rye in inhibiting root-knot nematode populations in soil," Applied Soil Ecology, vol. 15, no. 3, pp. 243-251, 2000.

[50] H.-S. Wu, Y.-D. Liu, G.-M. Zhao, X.-Q. Chen, X.-N. Yang, and X.-D. Zhou, "Succinic acid inhibited growth and pathogenicity of in vitro soil-borne fungus Fusarium oxysporum f. sp.
Niveum," Acta Agriculturae Scandinavica Section B, vol. 61, no. 5, pp. 404-409, 2011.

[51] S.-H. Park, M.-R. Choi, J.-W. Park et al., "Use of organic acids to inactivate Escherichia coli O157:H7, Salmonella typhimurium, and Listeria monocytogenes on organic fresh apples and lettuce," Journal of Food Science, vol. 76, no. 6, pp. M293-M298, 2011.

[52] G. SongGui, W. XingXiang, and Z. TaoLin, "Effects of low molecular weight organic acids on phosphomonoesterase activity," Acta Pedologica Sinica, vol. 46, no. 6, pp. 1089-1095, 2009.

[53] Y. P. Chen, P. D. Rekha, A. B. Arun, F. T. Shen, W.-A. Lai, and C. C. Young, "Phosphate solubilizing bacteria from subtropical soil and their tricalcium phosphate solubilizing abilities," Applied Soil Ecology, vol. 34, no. 1, pp. 33-41, 2006.

[54] L. Ström, A. G. Owen, D. L. Godbold, and D. L. Jones, “Organic acid behaviour in a calcareous soil: sorption reactions and biodegradation rates," Soil Biology and Biochemistry, vol. 33, no. 15, pp. 2125-2133, 2001.

[55] S. L. Daniel, C. Pilsl, and H. L. Drake, "Anaerobic oxalate consumption by microorganisms in forest soils," Research in Microbiology, vol. 158, no. 3, pp. 303-309, 2007.

[56] V. Vranova, H. Zahradnickova, D. Janous et al., “The significance of D-amino acids in soil, fate and utilization by microbes and plants: review and identification of knowledge gaps," Plant and Soil, vol. 354, no. 1-2, pp. 21-39, 2012.

[57] W. Ling, L. Ren, Y. Gao, X. Zhu, and B. Sun, "Impact of lowmolecular-weight organic acids on the availability of phenanthrene and pyrene in soil," Soil Biology and Biochemistry, vol. 41, no. 10, pp. 2187-2195, 2009.

[58] J.-Q. Zhang and Y.-H. Dong, "Effect of low-molecular-weight organic acids on the adsorption of norfloxacin in typical variable charge soils of China," Journal of Hazardous Materials, vol. 151, no. 2-3, pp. 833-839, 2008.

[59] Q. Fu, Y. Dong, H. Hu, and Q. Huang, "Adsorption of the insecticidal protein of Bacillus thuringiensis subsp. kurstaki by soil minerals: effects of organic acid ligands," Applied Clay Science, vol. 37, no. 1-2, pp. 201-206, 2007.

[60] L. Tian, E. Dell, and W. Shi, "Chemical composition of dissolved organic matter in agroecosystems: correlations with soil enzyme activity and carbon and nitrogen mineralization," Applied Soil Ecology, vol. 46, no. 3, pp. 426-435, 2010.

[61] S. Yuan, Z. Xi, Y. Jiang et al., "Desorption of copper and cadmium from soils enhanced by organic acids," Chemosphere, vol. 68 , no. 7, pp. 1289-1297, 2007.

[62] P. Lombnæs, A. C. Chang, and B. R. Singh, "Organic ligand, competing cation, and $\mathrm{pH}$ effects on dissolution of zinc in soils," Pedosphere, vol. 18, no. 1, pp. 92-101, 2008.

[63] V. Ettler, R. Vrtišková, M. Mihaljevič, O. Šebek, T. Grygar, and P. Drahota, "Cadmium, lead and zinc leaching from smelter fly ash in simple organic acids-Simulators of rhizospheric soil solutions," Journal of Hazardous Materials, vol. 170, no. 2-3, pp. 1264-1268, 2009.

[64] F. Debela, J. M. Arocena, R. W. Thring, and T. Whitcombe, "Organic acid-induced release of lead from pyromorphite and its relevance to reclamation of $\mathrm{Pb}$-contaminated soils," Chemosphere, vol. 80, no. 4, pp. 450-456, 2010.

[65] M. W. H. Evangelou, M. Ebel, and A. Schaeffer, "Evaluation of the effect of small organic acids on phytoextraction of $\mathrm{Cu}$ and $\mathrm{Pb}$ from soil with tobacco Nicotiana tabacum," Chemosphere, vol. 63, no. 6, pp. 996-1004, 2006.

[66] L. H. Wu, Y. M. Luo, P. Christie, and M. H. Wong, "Effects of EDTA and low molecular weight organic acids on soil solution 
properties of a heavy metal polluted soil," Chemosphere, vol. 50, no. 6, pp. 819-822, 2003.

[67] F. Qin, X.-Q. Shan, and B. Wei, "Effects of low-molecular-weight organic acids and residence time on desorption of $\mathrm{Cu}, \mathrm{Cd}$, and Pb from soils," Chemosphere, vol. 57, no. 4, pp. 253-263, 2004.

[68] G. Renella, L. Landi, and P. Nannipieri, "Degradation of low molecular weight organic acids complexed with heavy metals in soil," Geoderma, vol. 122, no. 2-4, pp. 311-315, 2004.

[69] A. P. Schwab, Y. He, and M. K. Banks, "The influence of organic ligands on the retention of lead in soil," Chemosphere, vol. 61, no. 6, pp. 856-866, 2005.

[70] C. W. A. Do Nascimento, D. Amarasiriwardena, and B. Xing, "Comparison of natural organic acids and synthetic chelates at enhancing phytoextraction of metals from a multi-metal contaminated soil," Environmental Pollution, vol. 140, no. 1, pp. 114-123, 2006.

[71] Y.-D. Jing, Z.-L. He, and X.-E. Yang, "Role of soil rhizobacteria in phytoremediation of heavy metal contaminated soils," Journal of Zhejiang University B, vol. 8, no. 3, pp. 192-207, 2007.

[72] A. P. Schwab, D. S. Zhu, and M. K. Banks, "Influence of organic acids on the transport of heavy metals in soil," Chemosphere, vol. 72, no. 6, pp. 986-994, 2008.

[73] P. N. Chiang, M. K. Wang, P. M. Huang, and J. J. Wang, "Effects of low molecular weight organic acids on137Cs release from contaminated soils," Applied Radiation and Isotopes, vol. 69, no. 6, pp. 844-851, 2011.

[74] J. Wen, S. P. Stacey, M. J. McLaughlin, and J. K. Kirby, "Biodegradation of rhamnolipid, EDTA and citric acid in cadmium and zinc contaminated soils," Soil Biology and Biochemistry, vol. 41, no. 10, pp. 2214-2221, 2009.

[75] L. Huang, H. Hu, X. Li, and L. Y. Li, "Dissolution of rockforming minerals in organic acids: simulated first stage weathering of fresh mineral surface," Applied Clay Science, vol. 49, no. 3, pp. 281-287, 2010.

[76] Y. Gao, J. He, W. Ling, H. Hu, and F. Liu, "Effects of organic acids on copper and cadmium desorption from contaminated soils," Environment International, vol. 29, no. 5, pp. 613-618, 2003.

[77] H.-Q. Hu, H.-L. Liu, J.-Z. He, and Q.-Y. Huang, "Effect of selected organic acids on cadmium sorption by variable-and permanent-charge soils 11 project supported by the national natural sciences foundation of china (No. 40371065)," Pedosphere, vol. 17, no. 1, pp. 117-123, 2007.

[78] W. H. Huang and W. D. Keller, "Dissolution of rock-forming minerals in organic acids: simulated first stage weathering of fresh mineral surface," American Mineralogist, vol. 55, no. 11-12, pp. 2076-2094, 1970.

[79] C. S. Vogel and J. O. Dawson, "In vitro growth of five Frankia isolates in the presence of four phenolic acids and juglone," Soil Biology and Biochemistry, vol. 18, no. 2, pp. 227-231, 1986.

[80] S. Caspersen, B. W. Alsanius, P. Sundin, and P. Jensén, "Bacterial amelioration of ferulic acid toxicity to hydroponically grown lettuce (Lactuca sativa L.)," Soil Biology and Biochemistry, vol. 32, no. 8-9, pp. 1063-1070, 2000.

[81] R.-K. Xu, Y.-G. Zhu, and D. Chittleborough, "Phosphorus release from phosphate rock and iron phosphate by lowmolecular-weight organic acids," Journal of Environmental Sciences, vol. 16, no. 1, pp. 5-8, 2004.

[82] J. Li and R. Xu, "Adsorption of phthalic acid and salicylic acid and their effect on exchangeable $\mathrm{Al}$ capacity of variable-charge soils," Journal of Colloid and Interface Science, vol. 306, no. 1, pp. 3-10, 2007.
[83] B. R. Dalton, “The occurrence and behavior of plant phenolic acids in soil environment and their potential involvement in allelochemical interference interactions: methodological limitations in establishing conclusive proof of allelopathy," in Principles and Practices in Plant Ecology: Allelochemical Interactions, Inderjit, K. M. M. Dakshini and C. L. Foy, Eds., pp. 57-74, CRC, Boca Raton, Fla, USA, 1999.

[84] A. Evans Jr., "Biodegradation of 14C-labeled low molecular organic acids using three biometer methods," Journal of Geochemical Exploration, vol. 65, no. 1, pp. 17-25, 1998.

[85] E. Oburger, G. J. D. Kirk, W. W. Wenzel, M. Puschenreiter, and D. L. Jones, "Interactive effects of organic acids in the rhizosphere," Soil Biology and Biochemistry, vol. 41, no. 3, pp. 449-457, 2009.

[86] J. Li, R. Xu, S. Xiao, and G. Ji, "Effect of low-molecular-weight organic anions on exchangeable aluminum capacity of variable charge soils," Journal of Colloid and Interface Science, vol. 284, no. 2, pp. 393-399, 2005.

[87] J. Li, R. Xu, D. Tiwari, and G. Ji, "Effect of low-molecular-weight organic acids on the distribution of mobilized Al between soil solution and solid phase," Applied Geochemistry, vol. 21, no. 10, pp. 1750-1759, 2006.

[88] K. W. Goyne, S. L. Brantley, and J. Chorover, "Effects of organic acids and dissolved oxygen on apatite and chalcopyrite dissolution: implications for using elements as organomarkers and oxymarkers," Chemical Geology, vol. 234, no. 1-2, pp. 28-45, 2006.

[89] K. W. Goyne, S. L. Brantley, and J. Chorover, "Rare earth element release from phosphate minerals in the presence of organic acids," Chemical Geology, vol. 278, no. 1-2, pp. 1-14, 2010.

[90] K. Singh and S. Mohan, "Adsorption behavior of selected monosaccharides onto an alumina interface," Journal of Colloid and Interface Science, vol. 270, no. 1, pp. 21-28, 2004.

[91] H. Fischer, A. Meyer, K. Fischer, and Y. Kuzyakov, "Carbohydrate and amino acid composition of dissolved organic matter leached from soil," Soil Biology and Biochemistry, vol. 39, no. 11, pp. 2926-2935, 2007.

[92] W. Zhang, H. He, and X. Zhang, "Determination of neutral sugars in soil by capillary gas chromatography after derivatization to aldononitrile acetates," Soil Biology and Biochemistry, vol. 39, no. 10, pp. 2665-2669, 2007.

[93] X. Zhang, W. Amelung, Y. Yuan, S. Samson-Liebig, L. Brown, and W. Zech, "Land-use effects on amino sugars in particle size fractions of an Argiudoll," Applied Soil Ecology, vol. 11, no. 2-3, pp. 271-275, 1999.

[94] D. A. N. Ussiri and C. E. Johnson, "Characterization of organic matter in a northern hardwood forest soil by ${ }^{13} \mathrm{C}$ NMR spectroscopy and chemical methods," Geoderma, vol. 111, no. 1-2, pp. 123-149, 2003.

[95] B. Allard, "A comparative study on the chemical composition of humic acids from forest soil, agricultural soil and lignite deposit: bound lipid, carbohydrate and amino acid distributions," Geoderma, vol. 130, no. 1-2, pp. 77-96, 2006.

[96] C. Keeler, E. F. Kelly, and G. E. Maciel, "Chemical-structural information from solid-state ${ }^{13} \mathrm{C}$ NMR studies of a suite of humic materials from a lower montane forest soil, Colorado, USA," Geoderma, vol. 130, no. 1-2, pp. 124-140, 2006.

[97] C. Jolivet, D. A. Angers, M. H. Chantigny, F. Andreux, and D. Arrouays, "Carbohydrate dynamics in particle-size fractions of sandy spodosols following forest conversion to maize cropping," Soil Biology and Biochemistry, vol. 38, no. 9, pp. 2834-2842, 2006. 
[98] G. Guggenberger, W. Zech, and R. J. Thomas, "Lignin and carbohydrate alteration in particle-size separates of an oxisol under tropical pastures following native savanna," Soil Biology and Biochemistry, vol. 27, no. 12, pp. 1629-1638, 1995.

[99] M. Fatima Begonia and R. J. Kremer, "Chemotaxis of deleterious rhizobacteria to birdsfoot trefoil," Applied Soil Ecology, vol. 11, no. 1, pp. 35-42, 1999.

[100] S. Haase, G. Neumann, A. Kania, Y. Kuzyakov, V. Römheld, and E. Kandeler, "Elevation of atmospheric $\mathrm{CO}_{2}$ and $\mathrm{N}$ nutritional status modify nodulation, nodule-carbon supply, and root exudation of Phaseolus vulgaris L," Soil Biology and Biochemistry, vol. 39, no. 9, pp. 2208-2221, 2007.

[101] J. K. Nieminen, "Wood ash effects on soil fauna and interactions with carbohydrate supply: a minireview," in Recycling of Biomass Ashes, H. Insam and B. A. Knapp, Eds., pp. 45-56, Springer, Berlin, Germany, 2011.

[102] P. Rovira and V. R. Vallejo, "Labile and recalcitrant pools of carbon and nitrogen in organic matter decomposing at different depths in soil: an acid hydrolysis approach," Geoderma, vol. 107, no. 1-2, pp. 109-141, 2002.

[103] A. Gallardo and J. Merino, "Soil nitrogen dynamics in response to carbon increase in a Mediterranean shrubland of SW Spain," Soil Biology and Biochemistry, vol. 30, no. 10-11, pp. 1349-1358, 1998.

[104] S. Gross and B. Glaser, "Minimization of carbon addition during derivatization of monosaccharides for compound-specific $\delta 13 \mathrm{C}$ analysis in environmental research," Rapid Communications in Mass Spectrometry, vol. 18, no. 22, pp. 2753-2764, 2004.

[105] A. Schmitt and B. Glaser, "Organic matter dynamics in a temperate forest soil following enhanced drying," Soil Biology and Biochemistry, vol. 43, no. 3, pp. 478-489, 2011.

[106] J. M. Oades, "Soil organic matter and structural stability: mechanisms and implications for management," Plant and Soil, vol. 76, no. 1-3, pp. 319-337, 1984.

[107] P. Roberts, R. Bol, and D. L. Jones, "Free amino sugar reactions in soil in relation to soil carbon and nitrogen cycling," Soil Biology and Biochemistry, vol. 39, no. 12, pp. 3081-3092, 2007.

[108] X. Zhang and W. Amelung, "Gas chromatograph1c determination of muramic acid, glucosamine, mannosamine, and galactosamine in soils," Soil Biology and Biochemistry, vol. 28, no. 9, pp. 1201-1206, 1996.

[109] B. Engelking, H. Flessa, and R. G. Joergensen, "Shifts in amino sugar and ergosterol contents after addition of sucrose and cellulose to soil," Soil Biology and Biochemistry, vol. 39, no. 8, pp. 2111-2118, 2007.

[110] B. Glaser, M.-B. Turrión, and K. Alef, "Amino sugars and muramic acid-biomarkers for soil microbial community structure analysis," Soil Biology and Biochemistry, vol. 36, no. 3, pp. 399-407, 2004.

[111] R. G. Joergensen, B. Meyer, and T. Mueller, "Time-course of the soil microbial biomass under wheat: a one year field study," Soil Biology and Biochemistry, vol. 26, no. 8, pp. 987-994, 1994.

[112] R. G. Joergensen, T. Mueller, and V. Wolters, "Total carbohydrates of the soil microbial biomass in $0.5 \mathrm{M} \mathrm{K}_{2} \mathrm{SO}_{4}$ soil extracts," Soil Biology and Biochemistry, vol. 28, no. 9, pp. 1147$1153,1996$.

[113] R. M. Johnson and K. S. Pregitzer, "Concentration of sugars, phenolic acids, and amino acids in forest soils exposed to elevated atmospheric $\mathrm{CO}_{2}$ and $\mathrm{O}_{3}$," Soil Biology and Biochemistry, vol. 39, no. 12, pp. 3159-3166, 2007.
[114] S. Elmholt, P. Schjønning, L. J. Munkholm, and K. Debosz, "Soil management effects on aggregate stability and biological binding," Geoderma, vol. 144, no. 3-4, pp. 455-467, 2008.

[115] J. K. Adesodun, J. S. C. Mbagwu, and N. Oti, "Structural stability and carbohydrate contents of an ultisol under different management systems," Soil and Tillage Research, vol. 60, no. 3-4, pp. 135-142, 2001.

[116] R. Mikutta, G. E. Schaumann, D. Gildemeister et al., "Biogeochemistry of mineral-organic associations across a long-term mineralogical soil gradient (0.3-4100 kyr), Hawaiian Islands," Geochimica et Cosmochimica Acta, vol. 73, no. 7, pp. 2034-2060, 2009.

[117] S. Schlecht-Pietsch, U. Wagner, and T.-H. Anderson, "Changes in composition of soil polysaccharides and aggregate stability after carbon amendments to different textured soils," Applied Soil Ecology, vol. 1, no. 2, pp. 145-154, 1994.

[118] L. V. Verchot, L. Dutaur, K. D. Shepherd, and A. Albrecht, "Organic matter stabilization in soil aggregates: understanding the biogeochemical mechanisms that determine the fate of carbon inputs in soils," Geoderma, vol. 161, no. 3-4, pp. 182-193, 2011.

[119] D. Cosentino, C. Chenu, and Y. Le Bissonnais, "Aggregate stability and microbial community dynamics under dryingwetting cycles in a silt loam soil," Soil Biology and Biochemistry, vol. 38, no. 8, pp. 2053-2062, 2006.

[120] M. Yousefi, M. Hajabbasi, and H. Shariatmadari, "Cropping system effects on carbohydrate content and water-stable aggregates in a calcareous soil of Central Iran," Soil and Tillage Research, vol. 101, no. 1-2, pp. 57-61, 2008.

[121] C. Mertz, M. Kleber, and R. Jahn, "Soil organic matter stabilization pathways in clay sub-fractions from a time series of fertilizer deprivation," Organic Geochemistry, vol. 36, no. 9, pp. 1311-1322, 2005.

[122] P. Puget, D. A. Angers, and C. Chenu, "Nature of carbohydrates associated with water-stable aggregates of two cultivated soils," Soil Biology and Biochemistry, vol. 31, no. 1, pp. 55-63, 1999.

[123] D. Derrien, C. Marol, and J. Balesdent, "Microbial biosyntheses of individual neutral sugars among sets of substrates and soils," Geoderma, vol. 139, no. 1-2, pp. 190-198, 2007.

[124] A. Miltner and W. Zech, "Carbohydrate decomposition in beech litter as influenced by aluminium, iron and manganese oxides," Soil Biology and Biochemistry, vol. 30, no. 1, pp. 1-7, 1998.

[125] E. Marín-Spiotta, C. W. Swanston, M. S. Torn, W. L. Silver, and S. D. Burton, "Chemical and mineral control of soil carbon turnover in abandoned tropical pastures," Geoderma, vol. 143, no. 1-2, pp. 49-62, 2008.

[126] T. Osono, S. Hobara, T. Hishinuma, and J.-I. Azuma, "Selective lignin decomposition and nitrogen mineralization in forest litter colonized by Clitocybe sp," European Journal of Soil Biology, vol. 47, no. 2, pp. 114-121, 2011.

[127] A. Traversa, V. D’Orazio, and N. Senesi, "Properties of dissolved organic matter in forest soils: influence of different plant covering," Forest Ecology and Management, vol. 256, no. 12, pp. 2018-2028, 2008.

[128] L. J. Sanger, P. Cox, P. Splatt, M. Whelan, and J. M. Anderson, "Variability in the quality and potential decomposability of Pinus sylvestris litter from sites with different soil characteristics: acid detergent fibre (ADF) and carbohydrate signatures," Soil Biology and Biochemistry, vol. 30, no. 4, pp. 455-461, 1998.

[129] C. Rumpel, K. Eusterhues, and I. Kögel-Knabner, "Noncellulosic neutral sugar contribution to mineral associated 
organic matter in top- and subsoil horizons of two acid forest soils," Soil Biology and Biochemistry, vol. 42, no. 2, pp. 379-382, 2010.

[130] G. D. Bending, M. K. Turner, F. Rayns, M.-C. Marx, and M. Wood, "Microbial and biochemical soil quality indicators and their potential for differentiating areas under contrasting agricultural management regimes," Soil Biology and Biochemistry, vol. 36, no. 11, pp. 1785-1792, 2004.

[131] C. Rumpel and M.-F. Dignac, "Gas chromatographic analysis of monosaccharides in a forest soil profile: analysis by gas chromatography after trifluoroacetic acid hydrolysis and reductionacetylation," Soil Biology and Biochemistry, vol. 38, no. 6, pp. 1478-1481, 2006.

[132] P. Rovira and V. Ramón Vallejo, "Labile, recalcitrant, and inert organic matter in Mediterranean forest soils," Soil Biology and Biochemistry, vol. 39, no. 1, pp. 202-215, 2007.

[133] C. Liang and T. C. Balser, "Preferential sequestration of microbial carbon in subsoils of a glacial-landscape toposequence, Dane County, WI, USA," Geoderma, vol. 148, no. 1, pp. 113-119, 2008.

[134] P. M. Medeiros, M. F. Fernandes, R. P. Dick, and B. R. T. Simoneit, "Seasonal variations in sugar contents and microbial community in a ryegrass soil," Chemosphere, vol. 65 , no. 5 , pp. 832-839, 2006.

[135] M. Kawahigashi, H. Sumida, and K. Yamamoto, "Seasonal changes in organic compounds in soil solutions obtained from volcanic ash soils under different land uses," Geoderma, vol. 113, no. 3-4, pp. 381-396, 2003.

[136] S. Hu, D. C. Coleman, P. F. Hendrix, and M. H. Beare, "Biotic manipulation effects on soil carbohydrates and microbial biomass in a cultivated soil," Soil Biology and Biochemistry, vol. 27, no. 9, pp. 1127-1135, 1995.

[137] T. L. Thompson, E. Zaady, P. Huancheng, T. B. Wilson, and D. A. Martens, "Soil C and N pools in patchy shrublands of the Negev and Chihuahuan Deserts," Soil Biology and Biochemistry, vol. 38, no. 7, pp. 1943-1955, 2006.

[138] J. A. J. Dungait, R. Bol, I. D. Bull, and R. P. Evershed, “Tracking the fate of dung-derived carbohydrates in a temperate grassland soil using compound-specific stable isotope analysis," Organic Geochemistry, vol. 40, no. 12, pp. 1210-1218, 2009.

[139] M. Spohn and L. Giani, "Impacts of land use change on soil aggregation and aggregate stabilizing compounds as dependent on time," Soil Biology and Biochemistry, vol. 43, no. 5, pp. 10811088, 2011.

[140] S. Hu, D. C. Coleman, C. R. Carroll, P. F. Hendrix, and M. H. Beare, "Labile soil carbon pools in subtropical forest and agricultural ecosystems as influenced by management practices and vegetation types," Agriculture, Ecosystems and Environment, vol. 65, no. 1, pp. 69-78, 1997.

[141] M. H. Beare, S. Hu, D. C. Coleman, and P. F. Hendrix, "Influences of mycelial fungi on soil aggregation and organic matter storage in conventional and no-tillage soils," Applied Soil Ecology, vol. 5, no. 3, pp. 211-219, 1997.

[142] F. Caravaca, M. M. Alguacil, R. Azcón, G. Díaz, and A. Roldán, "Comparing the effectiveness of mycorrhizal inoculation and amendment with sugar beet, rock phosphate and Aspergillus niger to enhance field performance of the leguminous shrub Dorycnium pentaphyllum L," Applied Soil Ecology, vol. 25, no. 2, pp. 169-180, 2004.

[143] R. Spaccini, J. S. C. Mbagwu, C. A. Igwe, P. Conte, and A. Piccolo, "Carbohydrates and aggregation in lowland soils of Nigeria as influenced by organic inputs," Soil and Tillage Research, vol. 75, no. 2, pp. 161-172, 2004.

[144] A. M. Treonis, S. J. Grayston, P. J. Murray, and L. A. Dawson, "Effects of root feeding, cranefly larvae on soil microorganisms and the composition of rhizosphere solutions collected from grassland plants," Applied Soil Ecology, vol. 28, no. 3, pp. 203215, 2005.

[145] M. Tejada, C. Garcia, J. L. Gonzalez, and M. T. Hernandez, "Use of organic amendment as a strategy for saline soil remediation: influence on the physical, chemical and biological properties of soil," Soil Biology and Biochemistry, vol. 38, no. 6, pp. 1413-1421, 2006.

[146] S. Saha, V. Prakash, S. Kundu, N. Kumar, and B. L. Mina, "Soil enzymatic activity as affected by long term application of farm yard manure and mineral fertilizer under a rainfed soybean-wheat system in N-W Himalaya," European Journal of Soil Biology, vol. 44, no. 3, pp. 309-315, 2008.

[147] L. Carrasco, F. Caravaca, R. Azcón, and A. Roldán, "Soil acidity determines the effectiveness of an organic amendment and a native bacterium for increasing soil stabilisation in semiarid mine tailings," Chemosphere, vol. 74, no. 2, pp. 239-244, 2009.

[148] J. Kruse, A. Schlichting, J. Siemens, T. Regier, and P. Leinweber, "Pyrolysis-field ionization mass spectrometry and nitrogen $K$ edge XANES spectroscopy applied to bulk soil leachates-a case study," Science of the Total Environment, vol. 408, no. 20, pp. 4910-4915, 2010.

[149] M.-C. Larre-Larrouy and C. Feller, "Determination of carbohydrates in two ferrallitic soils: analysis by capillary gas chromatography after derivatization by silylation," Soil Biology and Biochemistry, vol. 29, no. 9-10, pp. 1585-1589, 1997.

[150] D. A. Martens and K. L. Loeffelmann, "Improved accounting of carbohydrate carbon from plants and soils," Soil Biology and Biochemistry, vol. 34, no. 10, pp. 1393-1399, 2002.

[151] T. Sariyildiz and J. M. Anderson, "Interactions between litter quality, decomposition and soil fertility: a laboratory study," Soil Biology and Biochemistry, vol. 35, no. 3, pp. 391-399, 2003.

[152] E. Eder, S. Spielvogel, A. Kölbl, G. Albert, and I. Kögel-Knabner, "Analysis of hydrolysable neutral sugars in mineral soils: improvement of alditol acetylation for gas chromatographic separation and measurement," Organic Geochemistry, vol. 41, no. 6, pp. 580-585, 2010.

[153] T. Murata, H. Tanaka, S. Yasue, R. Hamada, K. Sakagami, and Y. Kurokawa, "Seasonal variations in soil microbial biomass content and soil neutral sugar composition in grassland in the Japanese Temperate Zone," Applied Soil Ecology, vol. 11, no. 2-3, pp. 253-259, 1999.

[154] A. Higa, E. Miyamoto, L. U. Rahman, and Y. Kitamura, "Root tip-dependent, active riboflavin secretion by Hyoscyamus albus hairy roots under iron deficiency," Plant Physiology and Biochemistry, vol. 46, no. 4, pp. 452-460, 2008.

[155] M. C. B. Sulochana, "B-Vitamins in root exudates of cotton," Plant and Soil, vol. 16, no. 3, pp. 327-334, 1962.

[156] H. Kaňová, J. Carre, V. Vránová, K. Rejsek, and P. Formánek, "Organic compounds in root exudates of Miscanthus $\times$ Giganteus greef et deu and limitation of microorganisms in its rhizosphere bynutrients," Acta Universitatis Agriculturae et Silviculturae Mendelianae Brunensis, vol. 58, no. 5, pp. 203-208, 2010.

[157] R. Pinton, Z. Varanini, and P. Nannipieri, The Rhizosphere: Biochemistry and Organic Substances at the Soil-Plant Interface, CRC Press; Taylor-Francis Group, Boca Raton, Fla, USA, 2nd edition, 2007. 
[158] X. Ding, B. Zhang, X. Zhang, X. Yang, and X. Zhang, "Effects of tillage and crop rotation on soil microbial residues in a rainfed agroecosystem of northeast China," Soil and Tillage Research, vol. 114, no. 1, pp. 43-49, 2011.

[159] W. R. Cookson, D. V. Murphy, and M. M. Roper, "Characterizing the relationships between soil organic matter components and microbial function and composition along a tillage disturbance gradient," Soil Biology and Biochemistry, vol. 40, no. 3, pp. 763-777, 2008.

[160] B. A. Stevenson, G. P. Sparling, L. A. Schipper, B. P. Degens, and L. C. Duncan, "Pasture and forest soil microbial communities show distinct patterns in their catabolic respiration responses at a landscape scale," Soil Biology and Biochemistry, vol. 36, no. 1, pp. 49-55, 2004.

[161] A. R. McLeod, K. K. Newsham, and S. C. Fry, "Elevated UV-B radiation modifies the extractability of carbohydrates from leaf litter of Quercus robur," Soil Biology and Biochemistry, vol. 39, no. 1, pp. 116-126, 2007.

[162] S. Spielvogel, J. Prietzel, and I. Kögel-Knabner, "Changes of lignin phenols and neutral sugars in different soil types of a high-elevation forest ecosystem 25 years after forest dieback," Soil Biology and Biochemistry, vol. 39, no. 2, pp. 655-668, 2007.

[163] R. Kiem and I. Kögel-Knabner, "Contribution of lignin and polysaccharides to the refractory carbon pool in C-depleted arable soils," Soil Biology and Biochemistry, vol. 35, no. 1, pp. 101118, 2003.

[164] W. Rosenberg, K. G. J. Nierop, H. Knicker, P. A. De Jager, K. Kreutzer, and T. Weiß, "Liming effects on the chemical composition of the organic surface layer of a mature Norway spruce stand (Picea abies [L.] Karst.)," Soil Biology and Biochemistry, vol. 35, no. 1, pp. 155-165, 2003.

[165] M. Spohn and L. Giani, "Water-stable aggregates, glomalinrelated soil protein, and carbohydrates in a chronosequence of sandy hydromorphic soils," Soil Biology and Biochemistry, vol. 42, no. 9, pp. 1505-1511, 2010.

[166] N. Barrera-Bassols, J. A. Zinck, and E. Van Ranst, "Local soil classification and comparison of indigenous and technical soil maps in a Mesoamerican community using spatial analysis," Geoderma, vol. 135, pp. 140-162, 2006.

[167] M. Teplitski and S. Rajamani, "Signal and nutrient exchange in the interactions between soil algae and bacteria," in Biocommunication in Soil Microorganisms, G. Witzany, Ed., vol. 23, pp. 413-426, Springer, Berlin, Germany, 2011.

[168] O. Muter, K. Potapova, B. Limane et al., "The role of nutrients in the biodegradation of 2,4,6-trinitrotoluene in liquid andsoil," Journal of Environmental Management, vol. 98, no. 1, pp. 51-55, 2012.

[169] E. H. F. Abd El-Zaher, Y. A. G. Mahmoud, and M. M. Aly, "Effect of different concentrations of phenol on growth of some fungi isolated from contaminated soil," African Journal of Biotechnology, vol. 10, no. 8, pp. 1384-1392, 2011.

[170] D. Kafkewitz, F. Fava, and P. M. Armenante, "Effect for vitamins on the aerobic degradation of 2-chlorophenol, 4-chlorophenil, and 4-chlorobiphenyl," Applied Microbiology and Biotechnology, vol. 46, no. 4, pp. 414-421, 1996.

[171] S. A. Hashsham and D. L. Freedman, "Adsorption of vitamin $B_{12}$ to alumina, kaolinite, sand and sandy soil," Water Research, vol. 37, no. 13, pp. 3189-3193, 2003.

[172] A. M. Baya, R. S. Boethling, and A. Ramos-Cormenzana, "Vitamin production in relation to phosphate solubilization by soil bacteria," Soil Biology and Biochemistry, vol. 13, no. 6, pp. 527-531, 1981.
[173] A. I. Essien, B. L. Fetuga, and O. Osibanjo, “ $\beta$-carotene content and some characteristics of under-exploited seed oils of forest trees in Nigeria," Food Chemistry, vol. 32, no. 2, pp.109-116, 1989.

[174] R. Murcia, B. Rodelas, V. Salmerón, M. V. Martínez-Toledo, and J. González-López, "Effect of the herbicide simazine on vitamin production by Azotobacter chroococcum and Azotobacter vinelandii," Applied Soil Ecology, vol. 6, no. 2, pp. 187-193, 1997.

[175] J. Gonzalez-Lopez, V. Salmeron, J. Moreno, and A. RamosCormenzana, "Amino acids and vitamins produced by Azotobacter vinelandii atcc 12837 in chemically-defined media and dialysed soil media," Soil Biology and Biochemistry, vol. 15, no. 6, pp. 711-713, 1983.

[176] E. Strzelczyk and H. Rózycki, "Production of B-group vitamins by bacteria isolated from soil, rhizosphere, and mycorrhizosphere of pine (Pinus sylvestris L.)," Zentralblatt fur Mikrobiologie, vol. 140, no. 4, pp. 293-301, 1985.

[177] M. Damon, N. Z. Zhang, D. B. Haytowitz, and S. L. Booth, "Phylloquinone (vitamin K1) content of vegetables," Journal of Food Composition and Analysis, vol. 18, no. 8, pp. 751-758, 2005.

[178] J. Franzen, J. Bausch, D. Glatzle, and E. Wagner, "Distribution of vitamin $\mathrm{E}$ in spruce seedling and mature tree organs, and within the genus," Phytochemistry, vol. 30, no. 1, pp. 147-151, 1991.

[179] K. Guillén-Navarro, S. Encarnación, and M. F. Dunn, "Biotin biosynthesis, transport and utilization in rhizobia," FEMS Microbiology Letters, vol. 246, no. 2, pp. 159-165, 2005.

[180] S. Hodson, M. Croft, E. Deery, A. Smith, and M. Warren, "Algae acquire vitamin $B_{12}$ through a symbiotic relationship with bacteria," Comparative Biochemistry and Physiology A, vol. 146, article S222, 2007.

[181] F. Gómez, M. V. Martínez-Toledo, V. Salmerón, B. Rodelas, and J. González-López, "Influence of the insecticides profenofos and diazinon on the microbial activities of Azospirillum brasilense," Chemosphere, vol. 39, no. 6, pp. 945-957, 1999. 

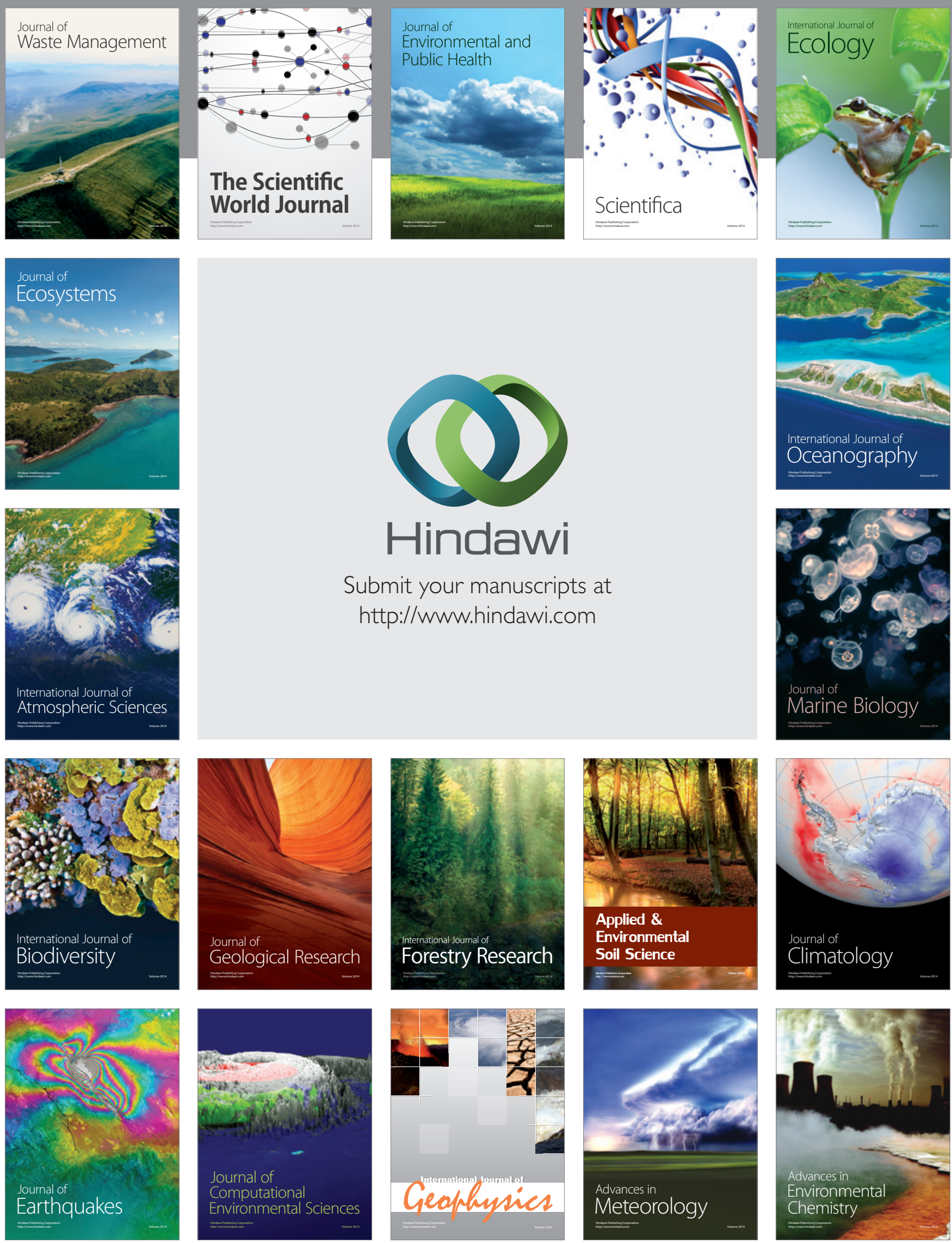